\title{
Conceptualizing Educational Tourism and the Educational Tourism Potential (evidence from ASEAN countries)
}

\author{
Anastasia A. Maga, PhD \\ Stamford International University, \\ Faculty of Business and Technology \\ Bangkok, Thailand \\ anastasia.maga@stamford.edu
}

\author{
Peter E. Nicolau \\ Stamford International University, \\ Faculty of Business and Technology \\ Bangkok, Thailand \\ peter.nicolau@stamford.edu
}

\begin{abstract}
The paper is an attempt to conceptualize the notion of educational tourism, which quite recently has piqued interest of economists as a potentially new, as it happens, old and forgotten, kind of tourism activities. We define educational tourism, delineate its boundaries with other types of tourism and education activities, and develop a theoretical framework for classification of academic mobility types, in which the main parameter for us is the time, duration of mobility. We also raise the issue of educational tourism potential (ETP) and try to assess it for ASEAN countries.
\end{abstract}

Key words - educational tourism, education, tourism, educational tourism potential

\section{INTRODUCTION}

Most of ASEAN countries have traditionally been exposed to increased international tourist interest, having the competitive advantage of warm climate and sea access. Thus the growth of tourism industry contributed lot to economic and social dimensions in countries such as Thailand, Indonesia, Malaysia, Vietnam, Cambodia, Singapore, Myanmar and Lao. More engagement into global economy brings more added value into the sector of such a competitive advantage. Albeit education plays an important role not only in tourism growth in terms of providing necessary human resource potential but also it happens to lead to a whole new avenue in added value creation educational tourism, defined as 'purposeful learning and travel' (Ritchie, 2003).

With growing numbers of incoming tourists, the absolute numbers of incoming students grows too, bringing more investment into local educational systems, especially in the form of taxes if private educational institutions are concerned. The case of ASEAN countries seems to prove this point with growing rates of inbound students' arrivals and growing ratio of private sector enrolments. We can assume that ASEAN countries do possess certain degree of educational tourism potential which if developed properly will bring in more added value.

Though some of the theoretical issues are still an unchartered territory in the study of educational tourism and its impact on the economic growth, so in this paper we will try to uncover the question of precisely defining what educational tourism is, and its boundaries within education and tourism. Another question for this paper is to define the educational tourism potential, what measure can be used to assess it. And finally this paper will try to evaluate the status quo of educational tourism in ASEAN countries.

\section{MATERIALS AND METHODS (MODEL)}

The very concept of educational tourism is not new to the extant research in both tourism and education. It is believed that the first mentioning of the phenomenon as an object of scholarly interest was under the term of 'educational travel' (Kalinowski \&Weler, 1992; Bodger, 1998; Randell, 1992) or edu-tourism (Holdnak \& Holland, 1996), which was defined as 'program in which participants travel to a location as a group with the primary purpose of engaging in a learning experience directly related to the location' (Bodger, 1998), or 'purposeful learning and travel' (Ritchie, 2005 referring to Paul, 2003).

Most literary impact has been made by the work of Ritchie (2003) and Smith and Jenner (1997), who define the parameters of educational tourism and even acknowledge that as all tourism broadens the mind all of it can be considered educational (Smith\& Jenner, 1997).

In terms of the object itself, Kaul (1985), Ritchie (2003), Haukeland et al. (2013) and others point out that the first forerunner to educational tourism as a phenomenon was the Grand Tour undertaken by British aristocracy in 17-19 centuries with the main purpose of civilizing the participants through a series of lasting tours around the countries of Europe (Ritchie, 2003) another example is the usual way of legal training acquisition for early American colonists, who 
travelled to the British Inns of Court to be trained for legal work back in the colonies and the newly formed American state. Since that time, and especially with more global involvement most countries in the world the phenomenon gained certain growth and nowadays we can see constantly growing numbers of student mobility over the years, namely it increased by nine times between 1963 and 2006 (Varghese, 2008). Other publications, for instance Canadian Tourism Commission (2001) and Rappolo (1996) also point out significant increase in the learning-oriented tourism experiences. Later studies try to quantify the parameter and measure the economic impact of educational tourism (Stroomberge, 2009) where the academics face the problem of the lack of statistical data, or rather lack of widely used statistical indicators able to measure the size and impact on educational tourism on an economy. Thus the issue of measurement prevails and in this paper we will try to suggest viable indicators to measure the size and impact of educational tourism on an economy.

Another problem is the definition. The currently used definitions and classifications of educational tourism vary widely from 'general interest while traveling' to 'purposeful learning' (Paul, 2003) thus the clear picture as to what to include in educational tourism and what not is lacking, as well as the quantifiable parameters. Ritchie (2003) suggests a theoretical framework of educational tourism which tries to classify the phenomenon by different parameters, including purpose, time, formality, intentions etc., where, again, the parameters are hardly quantifiable.

However the object has two dimensions and both of them have to be explored, and neither one of them shows consistency in research and statistical publications. Thus there is also a lack of understanding as to what to consider tourism and what not. The extant research in tourism marks the lower time limit of a travel to be considered tourism, a minimum of 24-hour stay is required (CTC, 2001) or an overnight stay by another definition (Weaver \& Opperman, 2000). However the maximum duration of stay to be considered a tourist is not clear, as long as different immigration requirements operate in different countries, for example EU has a clause of maximum 90 days (EACEA, 2017), and research papers disagree on the issue. For the purpose of this research we will use the WTO requirement of 12 consecutive month as a maximum (WTO, 2017).

In terms of the other parameter the extant research abound in suggestions as what to consider education, from Smith's classic (1982) 'the organized, systematic effort to foster learning, to establish the conditions, and to provide the activities through which learning can occur' to UNESCO's 'all learning activity undertaken throughout life, with the aim of improving knowledge, skills and/or qualifications for personal, social and/or professional reasons' (1984) pertaining more to LLL, however we will agree with Ritchie (2003) who associates education and learning for the purpose of defining educational tourism.

\section{METHODOLOGY}

The objective of this research is to define educational tourism, delimit its parameters, and create a classification of activities falling within educational tourism. We will also use the suggested framework to try to assess the importance and potential of educational tourism in ASEAN countries.

1) Defining educational tourism. In defining any notion there has to be precision about its structure. 'Educational tourism' has two main structural elements: the first and main is tourism, which includes the parameters of duration and mobility. For the purposes of this research we are using the WTO defined parameters of tourism which are 'tourism comprises the activities of persons traveling to and staying in places outside their usual environment for not more than one consecutive year for leisure, business and other purposes' (UNWTO). For the lower limit of duration we will use Weaver \& Opperman's 24 hours.

Education has a broader definition than that of tourism. However having agreed with UNESCO's definition of LLL, which we, for the purpose of this research will use as the foundation in educational tourism, because as we have established the said area refers to all knowledge improvements, but it has to be more precise than Smith \& Jenner's default interpretation of all tourism as educational.

Thus in educational tourism we are dealing with all learning activities undertaken outside of home geographical environment within a duration limit of between 24 hours and 12 consecutive months.

2) To delineate the boundaries of educational tourism from other types of tourism and education we need to develop a framework for further classification. For such a framework we will use two main variables - duration, as long as it is the main parameter of tourism dimension of the notion, and the level of educational attainment, as long as education is primarily classified into levels, and some of them can be attained within the specified range of time; another parameter to be considered is the formality, by which education is usually classified too. We will use the parameter of formality later within the framework.

For building the framework we will use the graphic approach and put the variables on a graph with $\mathrm{X}$ axis showing duration and $\mathrm{Y}$ axis showing the level of educational attainment, which we will quantify based on ISCED (1997) scale of educational levels augmented with our own observations, thus:

Level of educational attainment will range from 0 to 11 , with the following benchmarks:
0 - early childhood education
1 - primary education
2 - lower secondary education
3 - upper secondary education
4 - post-secondary non-tertiary education
5 - short-cycle tertiary education
6 - short-cycle non-tertiary education
7 - long-cycle tertiary education
8 - long-cycle non-tertiary education
9 - bachelor or equivalent education 
10 - masters' or equivalent education

11 - doctoral or equivalent education

On the 'duration' axis the data will be ordered from 24 hours to 12 consecutive years.

\section{RESULTS AND DISCUSSION}

Based on the acknowledged parameters we built a framework chart of educational tourism in the form of a scatter chart on which we plotted the types of educational tourism Fig. 1), however not all the types in the chart area fall within the definition of educational tourism simply deviating by duration, for which reason we divided the chart area into 2 fields (A and B) by the parameter of duration under 12 months and over 12 months.

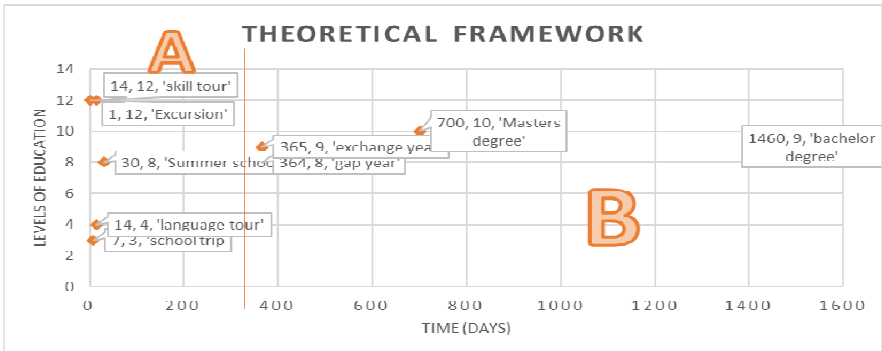

Fig 1 - Theoretical framework of academic mobility

As can be seen from the chart many levels of educational attainment fall into the field $\mathrm{B}$, which cannot be defined as educational tourism, thus has to be defined otherwise.

We suppose that there needs to be more definity about the usage of the terms and suggest to apply time limits, at least approximate ones, towards the terms 'tourism', 'mobility', also suggesting using the term 'migration' towards longer term relocation occurrences.

Analyzing the definition of 'mobility' itself we find a lot of controversy. On the one hand mobility is said to imply only leaving the usual geographical environment (if geographical mobility is meant), on the other hand in broader terms 'mobility' is used in economic geography to denote more permanent relocation ('labor mobility') or less permanent as in 'academic mobility'. Mobility as defined by United Nations Development Program (UNDP) as movement from one place of residence to another (UNDP, 2009), however we find the same definition of 'migration' in Clarke (1965), 'movement involving a change of residence for substantial duration'; Lee (1970) also defines migration as permanent or semi-permanent change of residence. Sinha (2005) agrees on a lack of conclusive definition of the term migration and quotes Newman and Matzke (1985) calling for distinguishing between the terms migration and circulation, both of which fall under the broader heading of mobility. Thus we suggest distinguishing between tourism and migration (agreeing with Newman and Matzke on defining circulation as permanent rotation of human resources, for instance commuters to work etc.). The boundary between mobility and migration is unidentified though, however this not being an object of this research we will accept OECD's limit of 12 months at least as a starting point of migration. Both terms 'tourism' and 'migration' are forms of mobility, thus in terms of academic mobility two types of mobility's exist - educational tourism and academic migration.

Thus in our chart (Fig. 1) the area A encompasses 'educational tourism' and the area B encompasses 'academic migration'.

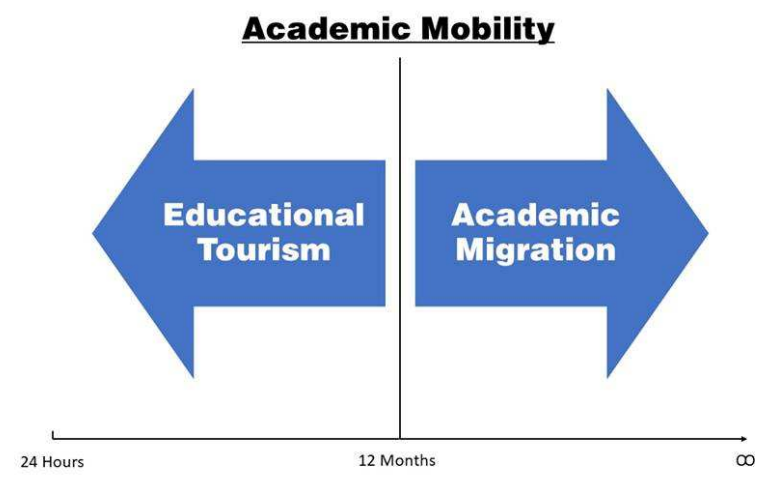

Fig. 2 Time framework of academic mobility

Therefore in our framework educational mobility ranges within the duration area of 24 hours to 12 months, and all learning activities taken and completed within this period can be categorized as educational tourism, so we place the following activities there:

$\begin{array}{ll}\text { - } & \text { Excursions } \\ \text { - } & \text { Summer camps } \\ \text { - } & \text { One yearses (under } 12 \text { months) and the like. } \\ \text { - } & \text { Gap year tours }\end{array}$

Having delineated the boundaries of educational tourism we need to try to assess its size and potential of such a kind of tourism. The problem with assessment and the reason why educational tourism is such an unpopular area of research is the lack of data on the topic in the statistical databases. So assessing the size or impact of educational tourism on an economy is rather a challenging task, also considering that companies rendering such services are usually small or medium sized enterprises (SMEs).

The said activities usually are paid thus the activity is commercial and creates added value, thus we consider educational mobility beneficial for local economies, it entails certain private investment and apart from short MBAs does not involve excessive public funding. Short MBAs are not numerous in the world, only some countries have such programs, thus their weight is highly insignificant.

Various sources (Sharma, 2005; Ritchie, 2003; Ankomah, 2000) mention classifying educational tourism activities by themes, which is an important point in our opinion in identifying the triggers for its growth. The most 
widely mentioned educational tourism themes are cultural, nature (eco), historical, and language.

Territories benefitting from educational tourism can have significant tax revenues from those activities altogether with new jobs creation and increased overall business activity. The question of the actual impact of educational tourism on the area is the one to be further explored. Ritchie and Priddle (2000) give a case of educational tourism in Canberra (Australia) and evaluate its total economic impact as $25 \mathrm{mln}$ AUS\$ in a year. Another good example is Malta and its highly popular LLE courses (Dimech, 2013).

We suggest that ASEAN countries, and especially Thailand, have sufficient qualities to become an attractive educational tourism destination. Most of the market for such a tourism comes from an immediate geographical vicinity (Russia, China, Asian countries, Middle East) and there are main tourist attractions growing in popularity.

In assessing the educational tourism potential we also should point out certain conditions without which the area would not be able to provide the services, those the essential elements of educational tourism infrastructure. We define them as follows:

presence of educational institutions (public and private, with private ones being more important because they provide more availability and flexibility);

- $\quad$ number of programmes in English;

- $\quad$ English proficiency (territorial); teachers; number of internationally qualified - presence of a general underlying trigger, such as climatic, historical or natural attraction measured also in growth of tourist inflows over years.

Thus, in case with ASEAN countries we see a stably growing number of tourists arriving each year $(9.4 \%$ of growth on the average for ASEAN) with Lao, Myanmar and Cambodia at the lead $(21.4 \%, 16.4 \%$ and $15.8 \%$ of average yearly growth respectively) (Appendix A). Such numbers prove that the underlying trigger exists and provides stable inflow of tourists (Fig. 3).

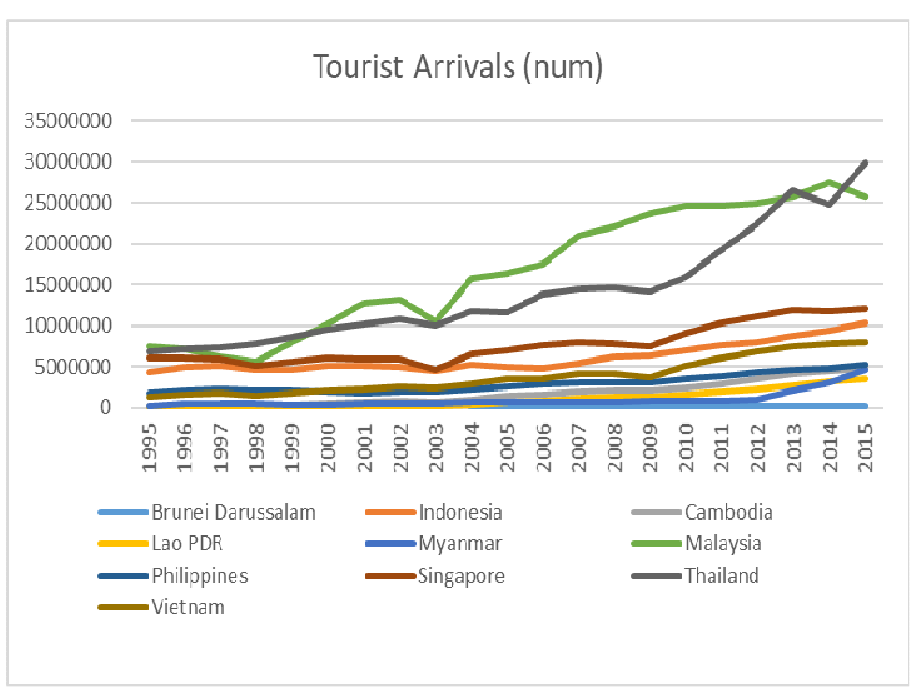

Fig. 3 - Tourist arrivals, ASEAN countries, 1995 - 2015 (UNICEF)

Figure 4 shows our approximate estimate of availability of private educational institutions in the ASEAN countries in dynamic aspect, again we can see that the share of students enrolled in private EIs is high and growing, with Indonesia and Cambodia in the lead with $65 \%$ and $67 \%$ respectively (Appendix B).

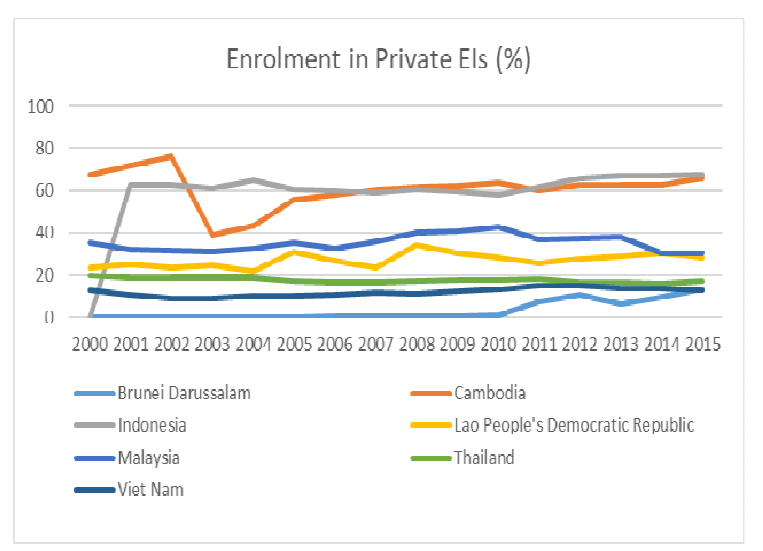

Fig. 4 - Enrolment in Private EIs (\%) (UNICEF)

In terms of programs offered in English Malaysia is the leader with 6 universities in top 1,000, offering 239 English-taught degrees, including 142 Bachelors and 97 Master's programs (Masters Portal, 2017). The overall statistic that roughly shows the availability of programs in English, as well as the number of international teachers, is the total number of incoming international students, in which category countries of ASEAN show significant and stable growth (with the only exception of Vietnam where the average annual growth over the period between 2006 2015 was $-1.3 \%$ ) (Appendix C), with Brunei, Thailand and 
Malaysia in the lead with $13.4 \%, 9.1 \%$ and $9.5 \%$ respectively.

English proficiency is measurable through the EF English Proficiency Index (EF EPI), in which ASEAN countries take the following places:

Table 1. ASEAN countries English Proficiency Index data

\begin{tabular}{c|c|c|c} 
Country & $\begin{array}{c}\text { EPI } \\
2017\end{array}$ & $\begin{array}{l}\text { Rank } \\
\text { (of } 80 \\
\text { countries ) }\end{array}$ & $\begin{array}{l}\text { Rank } \\
\text { (of 20 in } \\
\text { Asia) }\end{array}$ \\
\hline Singapore & 66.03 & 5 & 1 \\
\hline Malaysia & 61.07 & 13 & 2 \\
\hline Philippines & 60.59 & 15 & 3 \\
\hline Vietnam & 53.43 & 34 & 7 \\
\hline Indonesia & 52.15 & 39 & 10 \\
\hline Thailand & 49.78 & 53 & 15 \\
\hline Cambodia & 40.86 & 77 & 19 \\
\hline Lao PDR & 37.56 & 80 & 20
\end{tabular}

Table 1 data shows that ASEAN countries mainly have sufficient English proficiency to host tourists and international students, though some countries with growing inflow of tourists (Thailand, Cambodia and Lao PDR) have certain room for improvement of its educational tourism potential.

Our overall estimate of educational tourism potential (ETP) of ASEAN countries is positive, with most tourist attractive countries showing positive dynamics of ETP indicators.

\section{CONCLUSION}

Educational tourism remains an unpopular field of study due to lack of statistical data, though we argue that widely used statistical measures can and should be used to assess at least the potential for this type of tourism growth. Educational tourism is not a new concept but it has drawn considerable academic attention of late being a whole new opportunity to attract new investment to emerging markets, to which category most of ASEAN countries refer, and boost export figures. We defined educational tourism as 'all learning activities undertaken outside of home geographical environment within a duration limit of between 24 hours and 12 consecutive months' and delineated its boundaries with other types of mobility, pointed out what types of academic mobility are to be considered educational tourism and made an attempt to assess the ETP of ASEAN countries, however it is yet to be found out how and through which channels educational mobility impacts the territory. We agree with most authors (Ritchie, 2003; Smith, 2013; Ankomah et al., 2000; Sharma, 2015) that territories benefit from educational tourism but reserve it for further research as to what measures are to be taken to evaluate that impact. Further research must also include a more precise method of assessing the ETP of a territory.

\section{References}

Ankomah, P. K., \& Larson, R. T. (2000). Education Tourism: A Strategy to Strategy to Sustainable Tourism Development in Sub-Saharan Africa. DPMN Bulletin (Special Issue on Tourism and African Development: Trends and Critical Issues), 7(1), 19-24. Retrieved from http://www.dpmf.org/education-tourism-

paul.html\%5Cnhttps://www.cabdirect.org/cabdirect /abstract/20001811746

Bauziene, Z. (2012). The Significance of Voluntary Activity in The Organization of Self-Studies in Higher Education: The Case of Locomotion Disorder. Education Alternatives, 10(3), 67-78.

BODGER, D., 1998. LEISURE, LEARNING, AND TRAVEL. JOURNAL OF PHYSICAL EDUCATION. RECREATION \& DANCE, 69 (4), 28-31.

Canadian Tourism Commission (CTC) (2001) Learning Travel: 'Canadian Ed-Ventures' Learning Vacations in Canada: An Overview. Ontario: Canadian Tourism Commission.

Clarke, John Innes (1965). Population geography ([1st ed.]). Pergamon Press, Oxford ; New York

Dimech, Nicole Kim (2013) Educational tourism in Malta: an analysis of English Foreign Language (EFL) students: motivation, learning preferences and experience,

URL: https://www.um.edu.mt/library/oar//handle/123456 $789 / 7315$

Educational mobility. American Association of Colleges of Nursing (1998) Journal of professional nursing : official journal of the American Association of Colleges of Nursing, ISSN: 8755-7223, Vol: 14, Issue: 5, Page: 314-6

Educational Tourism: Strategy for Sustainable Tourism Development with reference of Hadauti and Shekhawati Regions of. (2015), 5(4), 1-17.

EF English Proficiency Index. URL: https://www.ef.co.

European Commission/EACEA/Eurydice, 2016. Structural Indicators on Graduate Employability in Europe 2016. Eurydice Report. Luxembourg: Publications Office of the European Union.

Globalization

(JANUARY 2008). https://doi.org/10.1007/978-3-642-36708-3_2

Haukeland, J. V., Vistad, O. I., \& Daugstad, K. (2013). Educational tourism and Interpretation (working paper).

Holdnak, A. and Holland, S. (1996) Edu-tourism: Vacationing to learn. Parks and Recreation 3 (9), 72-77.

ISCED: Glossary:International standard classification of education (ISCED), URL: http://ec.europa.eu/eurostat/statisticsexplained/index.php/Glossary:International_standa rd_classification_of_education_(ISCED) 
Kalinowski, K. M. \& Weiler, B.(1992). Educational Travel, New York, Wiley

Kaul, R. N. (1985). Dynamics of tourism: a trilogy. New Delhi: Sterling Publishers Private Limited

Lee, E. S. (1966). A Theory of Migration. Demography, 3(1), 47. ttps://doi.org/10.2307/2060063

MastersPortal.eu:

http://www.mastersportal.eu/articles/1726/top-5countries-in-asia-offering-the-most-english-taughtcourses.html

Newman, J. L., \& Matzke, G. E. (1984). Population: patterns dynamics and prospects.

Organization for Economic Co-operation and Development. (2008). OECD glossary of statistical terms. Paris: OECD.

Ritchie, B. W. (2003). Managing Educational Tourism. Clevedon, UK: Channel View Publications.

Ritchie, B. W. and Priddle, M. (2000) International and domestic university students and tourism: The case of the Australian capital territory. Paper presented at the Australian Tourism and Hospitality Research Conference, Mt Buller, Australia, 2-5 February.

Roppolo, C. (1996) International education: What does this mean for universities and tourism? In M. Robinson, N. Evans and P. Callaghan (eds) Tourism and Cultural Change (pp. 191-201).

Sharma, A (2015) Educational Tourism: Strategy for Sustainable Tourism Development with reference of Hadauti and Shekhawati Regions of. (2015), $5(4), 1-17$.

Sinha, B. R. K. (2005). Human migration: concepts and approaches Concepts and meaning of migration. LIV. Évf. 3-4. Füzet, 403-414. Retrieved from http://www.mtafki.hu/konyvtar/kiadv/FE2005/FE2 0053-4_403-414.pdf

Smith, A. (2013). The role of educational tourism in raising academic standards. African Journal of Hospitality, Tourism and Leisure, 2(3), 1-7.

Smith, C. and Jenner, P. (1997a) Market segments: Educational tourism. Travel and Tourism Analyst 3, 60-75.

Smith, R (1982) Learning How to Learn. Chicago: Folett.

Stroomberge A. (2009) Measuring the economic impact of "export education"_ insights from New Zealand GlobalHigherEd., - February 7, 2009. https://globalhighered.wordpress.com

Turner, R. (2017). Travel and Tourism Economic Impact 2017: Thailand. London: World Travel \& Tourism Council (WTTC). Retrieved from https://www.wttc.org/-

/media/files/reports/economic-impactresearch/countries-2017/thailand2017.pdf

UNCTAD, U. N. C. on T. and D. (2002). FDI in Tourism: The Development Dimension (Vol. 2002).

UNDP (United Nations Development Program) (2009), Human Development Report 2009: Overcoming
Barriers: Human Mobility and Development, Basingstoke, Palgrave Macmillan.

UNESCO Institute of Statistics (2017), http://uis.unesco.org

UNESCO, Glossary of Migration Related Terms, URL: www.unesco.org/shs/migration/glossary

UNESCO. (2007). Operational Definition of Basic Education, (December 2007), 1-80.

UNESCO. Terminology of technical and vocational education UNESCO. 1984

Varghese, N.V. \& , UNESCO-IIEP. (2008). Globalization of Higher Education and Cross-Border Student Mobility. http://lst-iiep.iiep-unesco.org/cgibin/wwwi32.exe/[in=epidoc 1. in] $/$ ?t2000=025909/( $\underline{100)}$

Vistad, O. I., Wold, L. C., Daugstad, K., \& Haukeland, J. V. (2016). Mimisbrunnr Climate Park - A network for heritage learning, tourism development, and climate consciousness. Journal of Heritage Tourism, 11(1), 43-57. https://doi.org/10.1080/1743873X.2015.1082570

Weaver, D. and Oppermann, M. (2000) Tourism Management. Brisbane: John Wiley.

Willis, K. (2010). Introduction: mobility, migration and development. International Development Planning Review, 32(3-4), i--xiv. https://doi.org/10.3828/idpr.2010.15

World Bank (2009), World Development Report 2009: Reshaping Economic Geography, Washington, DC, World Bank.

WTO Terminology Database. URL: https://www.wto.org/english/thewto_e/glossary_e/gloss ary e.htm 